\title{
THE DOMINANCE OF MOTHER TONGUE WHILE STUDYING ENGLISH LANGUAGE IN VERNACULAR MEDIUM SCHOOLS
}

Ms. Chitra Sharma* | Dr. Shaifali Rachna Puri*

*Ph. D Scholar, Himalyan University, Arunachal Pradesh, India.

${ }^{* *}$ Research Guide, Himalayan University, Arunachal Pradesh, India. DOI: http://doi.org/10.47211/tg.2020.v07iws01.003

Received $12^{\text {th }}$ June 2020, Accepted $20^{\text {th }}$ June 2020, Available online $30^{\text {th }}$ June 2020.

\section{ABSTRACT:}

Studying English is a propagating ultimatum in this span of globalization. Many individuals endeavour to study this esteemed language. Nonetheless, it is a noteworthy element that each individual has complications of dominance of mother tongue while studying English language. Because, when a student is under coercion in second language, he will take empathetic words from the mother tongue and this is called dominance of mother tongue. In India the solemn docket, "English teaching through English language" is not abide by in the classes of English language in many vernacular medium schools of Kamrup, Assam. The faculties make use of the bilingual method to instruct English to the pupils. In this instance of inferior bilingualism, the second tongue is not learnt thoroughly, the mother tongue dominates as well as affects the second language and guides to dominance.

Key Words: Mother tongue, second language, dominance, bilingualism, vernacular school.

\section{ABOUT AUTHORS}

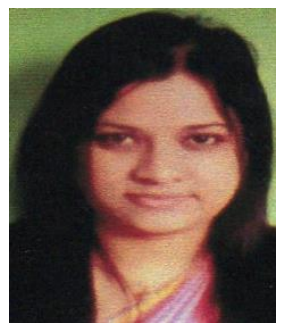

Author Ms. Chitra Sharma is a Ph. D. Scholar in Himalayan University, Arunachal Pradesh, India.

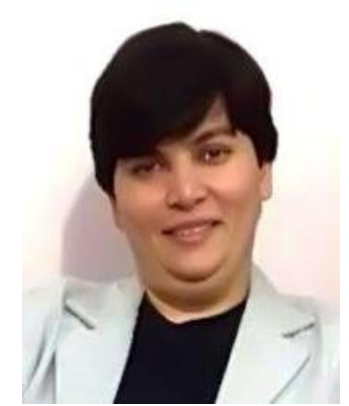

Author Dr. Shaifali Rachna Puri is a Research Guide in Himalayan University, Arunachal Pradesh, India. She has more than twenty publications to her credit and is a reputed social worker. 


\section{INTRODUCTION:}

The first language a child learns in its childhood by noticing the mother is familiar as mother tongue. And the language be owned by the others is second language. Mainly, any language excepting an individual's mother tongue is familiar as second language. English is an overseas language and consequently, its ranking is second language in the procedure of learning in India.

Studying English as second language to speak, read and write is extremely hard for learners of vernacular medium schools of Kamrup, Assam, since when thy study English at school, their intellect is boosted with their mother tongue and its grammar, edifice, etc. as well as their mother tongue is as a consequence aggregately manifested. Ultimately, receiving mother tongue, English is sensed tough. At the time they employ English, visibly their mother tongue dominates and compels them operate English incompetent while speaking and writing. When a student is beneath the compulsion in second language, he will take delegated words from the mother tongue and it's called the dominance of mother tongue. In the instance of inferior bilingualism, the second language is not learnt, the mother tongue dominates as well as impacts the second language and guides to the path of interference. The emergence of uneven rules of grammar and the dissimilar sound letters in English leads to the uncertainty in the intellect of the students of India, regardless of mother tongue team as every regional language in India are phonetic language, considering English is a non-phonetic language. And this is the leading complication faced by the students of Kamrup, Assam, as this is one of the regions of vast India.

The utilization of mother tongue in classrooms of English in Kamrup, Assam: In, Kamrup, Assam, the solemn docket "English through English teaching" is not fully abide by in the English classrooms in most of the vernacular medium schools. The medium of instruction in vernacular schools are different regional languages which are the mother tongue of the pupils. The faculties of English utilize the bilingual method to instruct the students in the English classrooms. Sometimes English is taught by further subject teachers or unskilled faculties. It is noticed that intemperate utilization of vernacular languages in Kamrup in the classrooms of English shears down the attentiveness. For that reason, a bull's eye is pinched and further on that, the utilization of mother tongue is not applicable. The study reveals that the medium of instruction in vernacular schools are in regional languages. But in higher education, the medium becomes English. As a result, after ten to twelve years of schooling in vernacular medium schools, the students move to colleges and universities for higher education where the students arrive to a separate medium of instruction which hampers rapid assumption.

When the students of vernacular background endeavour to talk and write in English, they grope and pause to proceed ahead caused by the anxiety to do error and condemnation. They anticipate their faculties to speak in vernacular language.

\section{OBSERVATION \& FINDINGS:}

The vernacular languages like Hindi, Assamese, Bengali and Nepali are not completely adjacent to English, the structural design is not identical as well as vocabulary along with syntax are not alike. Consequently, the students naturally realized this strenuous to speak and write in English. In consequence, the dominance of mother tongue was perceived for the students deriving from regional languages. Some of the grammatical components like, the application of articles, capitalization, auxiliary verbs, adjectives etc. and linguistic components like morphology, phonology, sentence structure, etc.

Between mother tongue and the second language, English are difficult zone for the students of vernacular medium schools.

The leading reason for the dominance of mother tongue is the translation of every single word of mother tongue to English because of the misapprehension that every language is same. In the above mentioned regional languages, considerable scrambling is practicable with contrasting pragmatic consequences, nonappearance of capitalization, no utilization of auxiliary verbs along with articles, sentence without verb as well as the chance of the word order in the sentence without changing the meaning, etc. forced the students muddled.

Another reason for the dominance of mother tongue is the hesitation of the students while shifting to the second language in ritualistic events. The research reveals that the pronunciation and dearth of listening expertise hamper the students to communicate suitably. In the English classrooms of vernacular medium school, students do not enjoy the role-plays, vocabulary brainstorming, drills and debates, practice speeches, which are fruitful source for studying English language.

\section{EXPLANATION:}

Some steps can be accepted to reduce the dominance of mother tongue on studying English for the students of vernacular backgrounds. Prohibition in case of mother tongue in the English classroom may be 
demonstrated the major step in this case. By arranging distinctive programme like inaugurating language workshop to adjust the pupils may be drawn as specimen. To obtain correct pronunciation in English with slighter dominance of mother tongue, modern spoken English can be launched by skilled faculties. Uninterrupted and robust should be offered in phonetics utilizing the workshops of English language to increase the students' skills of speaking and writing. The students must be forced to make use of English both inside as well as outside the classroom.

A faculty plays a crucial character in growing a student's expertness in English. All the answers and explanations should be received in English by the teachers in the English classroom, even though they are not correct and consequently motivate them to entail in the procedure of teaching and learning. The faculties require generating love as well as attentiveness for the target language amid the students. To banish the apprehensiveness, the educator should aptly prove the easiness of the English language. The faculty has to justify how it is easier to talk, read and write in English than other regional languages, even than the mother tongue. The instructor should inspire the pupils to open up their mouths with some words in English and later quicken the practice of speaking, reading and writing.

The learners should be the same as an automatic machine preferably than a manual machine. They should know to impel themselves without anticipating anybody to execute. They should transform their awkwardness in learning into demanding chances. They can take part in group discussions on simple topics of their interest, reading English newspapers and magazines, watching TV programs in English, chatting through social networking channels, listening radio, browsing internet, listening the recorded speeches of good speakers which assist them a good deal in magnifying speaking and writing potentiality in English.

\section{CONCLUSION:}

The present research scrutinizes the dominance of mother tongue disturb the students from studying English. In a balanced procedure the students at distinct level encourage linguistic, cultural and psychological robustness. The semantic participation in the living environment often flatters the basis of their succeeding studies. Consequently in lieu of utilizing mother tongue regularly in the classroom, the faculties especially cautiously, reasonably and methodically operate this in monolinguals, bilingual and multicultural classes accompanied by awareness and responsibility. The exact and proper application of lexical as well as syntactic stability between the mother tongue and the target language English encourages retentiveness and builds up the comprehension of the authentic harmony of language as well as culture.

REFERENCES:

1) Harbord, J. 1992. "The use of mother tongue in the class room". ELT Journal, 46/4, 350-355

2) Radhika, V. 2014. "Interference of Mother Tongue in Learning English as a Second language". Dissertation.

3) Dr. Chittaranjan Bhoi. 2014. "Role of Mother Tongue in Teaching -Learning English”. IJR. V. 3.

4) Iqbal, Yasir. 2016. "The influence of Mother Tongue on Learning a Foreign Language in the Kingdom of Bahrain".EJELLL, V. 3.

5) Mattioli, G. 2004. "On Native Language Instructions and Making Do with Words: Linguistically Homogenous Classrooms and Native Language Use". English Teacher Forum 42(4), 2025

6) Mc Key, S. 2002. Teaching English as an International language. Oxford: Oxford University Press. 